\title{
EL FENÓMENO DEL ESPEJO GOMO REFLEJO DEL JARDÍN CELESTE EN LA MEZQUITA REAL DE ISFAHĀN
}

\section{Antoni Gonzalo Garbó}

Universidad de Barcelona

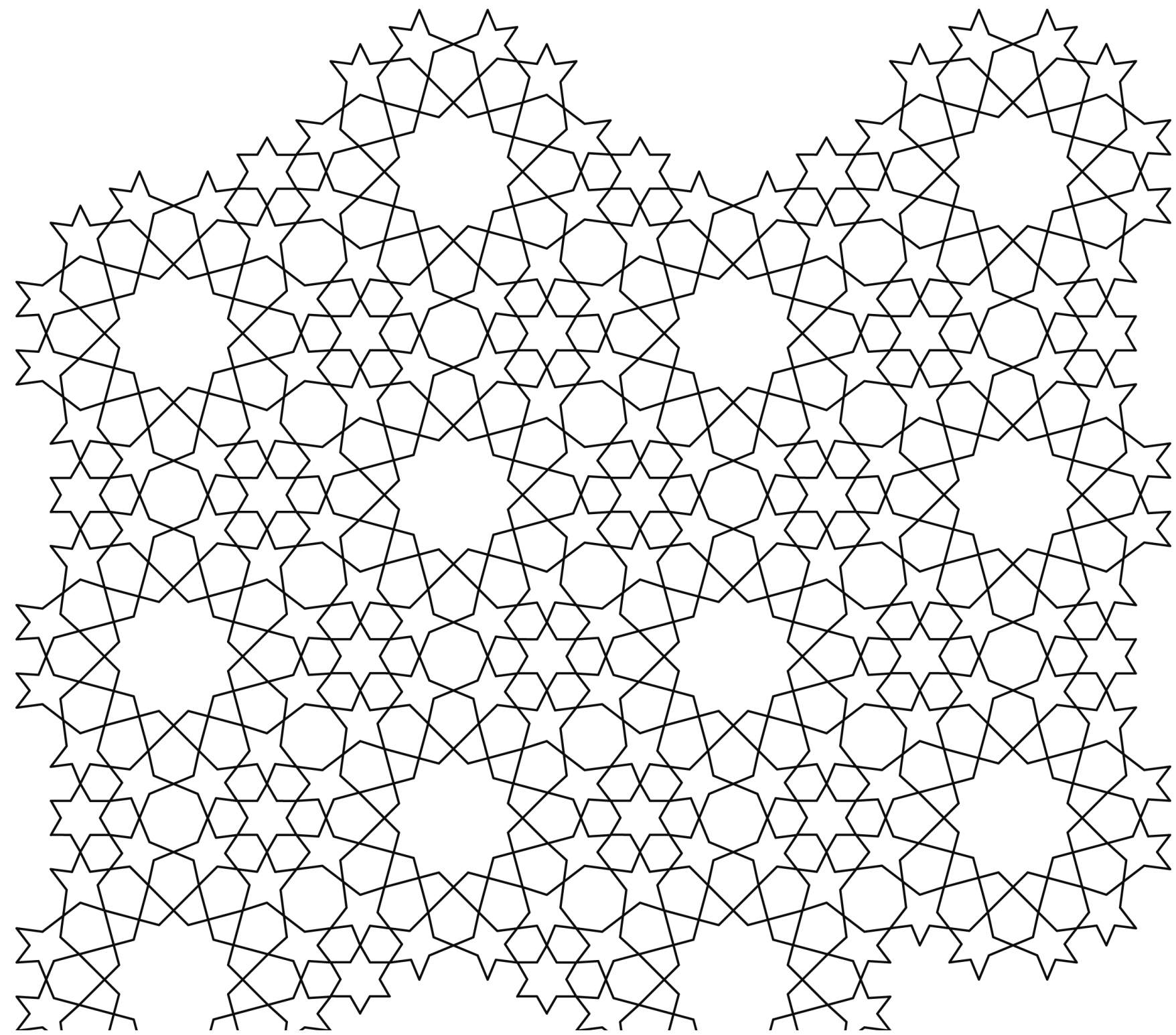

(*) Abreviaturas principales: ár. = árabe; Cor. = Corán; DIIFI = Département d'iranologie de l’Institut franco-iranien (de recherche), Teherán; EJMEL = Edebiyāt: The Journal of Middle Eastern Literatures; IFRI = Institut Français de Recherche en Iran, Teherán; París; Fus. = Ibn al-'Arabī, Fușūṣ al-hikam, ed. crítica 'A. 'A. 'Affîfí, Beirut: Dār al-Kitāb al-'Arabī, 1346/1946; Fut. = Ibn al-Arabī, al-Futūhāt al-makkiyya, El Cairo 1329/1911; reimpr. Beirut: Dār al-Ṣādir, s.d.; JMIAS = Journal of the Muhyiddin Ibn Arabi Society, Oxford; per. = persa. 


\section{ISFAHĀN: DE LA GIUDAD DE LOS SENTIDOS A LA GIUDAD «IMAGINAL»}

Louis Massignon habla del «Paraíso de los cuatro ríos que confluyen en el centro en el interior de un recinto cuadrado muy alto, en un espejo que debía ser objeto de la contemplación». Henry Corbin se inclina también a ello desvelando un «espejo que a través las palingenesias, refleja todavía el paisaje de gloria descrito por la cosmogonía mazdea de la mañana de los mundos: el concepto mismo del Jardín celeste, del paraíso». Ambos ven Irán con el ojo del jardín-paraíso1. Quizás hay en esta comunidad de visión una realidad más profunda que sobrepasa a ambos, pero de la cual son en cierto modo lo depositarios. Quizás esta realidad es el alma de Irán, esta substancia mágica que los antiguos iranios veían con el ojo del alma (ğăn chašm $)^{2}$.

1 Sobre el jardín simbólico en el islam, sobre el jardín persa como reflejo del Paraíso, como microcosmo de la cultura medieval irania o como mundo imaginal, véanse: M. Alemi, «Chahar bagh», Environmental design (Roma), 1 (1986), pp. 38-45; N. Ardalan, «The Paradise Garden Paradigm», en S. J. al-Dīn Āshtiyānī et al. (ed.), Consciousness E Reality: Studies in Memory of Toshihiko Izutsu, Leiden: E. J. Brill, pp. 112-9, esp. p. 112; N. Ardalan; L. Bakhtiar, The Sense of Unity: The Sufi Tradition in Persian Architecture, Chicago; Londres: The University of Chicago Press, 1973, pp. 34-5, 68 [trad. cast.: N. Ardalan; L. Bakhtiar, El sentido de la Unidad: la tradición sufi en la arquitectura persa, trad. C. Varona Narvión, Madrid: Siruela, 2007]; J. Brookes, Gardens of Paradise: The History and Design of the Great Islamic Gardens, Londres: Weidenfeld and Nicolson; Nueva York: New Amsterdam Books, 1987; E. Clark, The art of the Islamic garden, Ramsbury: Crowood, 2004; P. Hobhouse; E. Hunningher (ed.); J. Harpur (fotogr.), Gardens of Persia, Londres: Cassell Illustrated, 2003; Y. Ishaghpour, La miniature persane. Les couleurs de la lumière: le miroir et le jardin, París: Farrago, 1999; Sh. Katouzian, «The sense of place in Persian gardens», Environmental design (Roma), 2 (1986), pp. 42-47; M. Khansari; M. R. Moghtader; M. Yavari, The Persian Garden: Echoes of Paradise, Washington: Mage Publishers, 1998; J. Lehrman, Earthly Paradise: Garden and Courtyard in Islam, Berkeley, CA: University of California Press, 1980; E. B. MacDougall; R. Ettinghausen (ed.), The Islamic Garden, Washington, DC: Dumbarton Oaks, Trustees for Harvard University, 1976; E. B. Moynihan, Paradise as a Garden in Persia and Mughal India, Nueva York: George Braziller, Inc., 1979; Y. Porter (texto); A. Thévenart (fotogr.), Palais et jardins de Perse, París: Flammarion, 2002; D. F. Ruggles, Gardens, landscape, and vision in the palaces of Islamic Spain, University Park: Pennsylvania University Press, 2000 ; id., Islamic gardens and landscapes, Filadelfia: University of Pennsylvania, 2008; V. Sackville-West, «Los jardines persas», en A. J. Arberry (ed.), El legado de Persia, Madrid: Editorial Revista de Derecho Privado, 1967, pp. 407-57; H. Stierlin, Ispahan, Image du Paradis, Lausana; París: La Bibliothèque des Arts, 1976; M. E. Subtelny, Le monde est un jardin. Aspects de l'histoire culturelle de l'Iran médiéval, París: Association pour l'Avancement des Études Iraniennes, 2002; N. M. Titley, Plants and Gardens in Persian, Mughal and Turkish Art, Londres: British Library, 1979; D. N. Wilber, Persian Gardens and Garden Pavilions, Rutland, VT; Tokio: Charles E. Tuttle Co., 1962. Sobre el sentido alegórico del jardín en la literatura persa véanse: C.-H. de Fouchécour, La description de la nature dans la poésie lyrique persane du XI siècle. Inventaire et analyse des thèmes, París: Klincksieck, 1969; W. L. Hanaway, Jr., «Paradise on Earth: The Terrestrial Garden in Persian Literature», en MacDougall; Ettinghausen (ed.), The Islamic Garden, o.c., pp. 41-67; J. S. Meisami, «Allegorical Techniques in the Ghazals of Hāfez», EfMEL, 4 (1979), pp. 1-40; id., «The World's Pleasance: Hāfiz's Allegorical Gardens», Comparative Criticism, 5 (1983), pp. 153-85; id., «Allegorical Gardens in the Persian Poetic Tradition: Nezāmī, Rūmī, Hāfez», International fournal of Middle East Studies, 17 (1985), pp. 229-60; id., "The Body as a Garden: Nature and Sexuality in Persian Poetry». EJMEL, 6:2 (1995), pp. 245-74; id., Structure and Meaning In Medieval Arabic and Persian Poetry, Londres; Nueva York: RoutledgeCurzon, 2003, pp. 355 ss. et passim.; A. Schimmel, «The Celestial Garden in Islam», en MacDougall; Ettinghausen (ed.), The Islamic Garden, o.c., pp. 11-39.

2 Cf. el pref. de D. Shayegan a R. Grousset; L. Massignon; H. Massé (dir.), L'âme de l'Iran, 2ª ed. aument., París: 
Para comprender el sentido que el mundo intermedio (barzaḩ̋ $)$ de la Imaginación creadora $(h a y \bar{a} l)^{3}$ tiene en la mística islámica ${ }^{4}$, podemos recurrir a la significación simbólica de la arquitectura persa ${ }^{5}$. Algunas de las páginas que Henry Corbin ha consagrado a la bella ciudad de Isfahān muestran hasta qué punto él era sensible a la belleza del paisaje y del arte persas:

«Más de treinta años atrás, para el viajero que venía del sur por la ruta de Šīrāz, en un brusco viraje situado aún en la colina, Isfahān ofrecía a menudo la "visión de esmeralda" de sus jardines, sus "paraísos", de la cual emergían solas las cúpulas mismas verdeantes de sus mezquitas y de sus madrasah» ${ }^{6}$.

El oasis de Isfahān, la «ciudad azul», parece tipificar para nuestro autor el reflejo sensible de las ciudades míticas de esmeralda, a las que el viajero accede cuando ha alcanzado la montaña de Qāf. Henry Corbin habla tanto de la «visión de esmeralda» como del «fenómeno del espejo» que aparece en el espacio vacío de los nichos finamente rebajados de la cámara de música del palacio de 'Ālī Qāpū en Isfahān (principios del s. XVII ${ }^{7}$. Corbin le comentó a Daryush Shayegan de dichos nichos:

«Esto es el fenómeno del espejo, si acercas la mano a este vacío no tocas la forma, pues la imagen no está ahí, está en otra parte... en otra parte [...] quién sabe, quizás en ciudades maravillosas que se hallan a ambos lados de la montaña mágica, en el octavo clima: allí donde todos los cuerpos permanecen en suspensión semejantes a estas siluetas que ves flotando aquí» ${ }^{8}$.

Albin Michel, 1990 [1951], p. 24.

3 Cf., S. H. Bashier, Ibn al-Arabì's Barzakh. The Concept of the Limit and the Relationship between God and the World, Albany: State University of New York Press, 2005.

4 'A. 'Afífī, en su Com. a los de Fus. de Ibn al-'Arabī [ed. crítica de A. 'Afífī, Beirut: Dār al-Kutub al-Arabī, 1346/1946], define el «mundo de las Imágenes» ('ālam al-mitāll) como «un mundo realmente existente en que se hallan las formas de las cosas de un modo que oscila entre la "delicadeza" y la "tosquedad", o sea entre la pura espiritualidad y la pura materialidad». Las formas sensibles se vuelven espirituales en el mundo de la «materia inmaterial», según la clásica definición que nos da H. Corbin: «[...] entre el universo aprehensible por la pura percepción intelectual (el universo de las Inteligencias querubínicas) y el universo perceptible por los sentidos, existe un mundo intermedio, el de las Ideas-Imágenes, las Figuras-arquetipos, los cuerpos sutiles, la «materia inmaterial»; mundo tan real y objetivo, consistente y subsistente, como el mundo inteligible y el sensible, universo intermedio "en el que lo espiritual toma cuerpo y el cuerpo se torna espiritual" [...]». Cf. H. Corbin, La imaginación creadora en el sufismo de Ibn Arabī, Barcelona: Destino, 1993, p. 14.

5 Sobre el sentido de la unidad en el arte iraní, cf. Ardalan; Bakhtiar, The Sense of Unity, o.c.; L. Bakhtiar, Sufi, Expression of the Mystic Quest, reimpr., Londres: Avon Publishers of Brad; Thames and Hudson, 1997 [1976].

6 H. Corbin, «Les cités emblématiques», prefacio al libro de Stierlin, Ispahan, Image du Paradis, o.c., p. 5.

7 H. Corbin, En Islam iranien: Aspects spirituels et philosophiques, reimpr., 4 t., París: Gallimard, 1971-1972, t. I, p. XXI. 8 Apud D. Shayegan, «L’homme à la lampe magique», en S. H. Nasr (ed.), Mélanges offerts à Henry Corbin, Teherán: 
Pensadores como Šihāb al-Dīn Yahyà Suhrawardī conciben un cosmos entre el mundo corpóreo ('ālam-i barzah) y el mundo angélico ('ālam-i qahria), un mundo de formas e «imágenes suspendidas» (mutul mu'allaqa) o de «formas puras» (ašhāb al-muğarrada) ${ }^{9}$, como la imagen en el espejo, que no pertenecen ni se adecuan al ente material, sino que este último es el lugar donde se manifiestan. En este sentido, Suhrawardī afirma en su Libro de la Sabiduría oriental:

«La verdad es que las formas que vemos en los espejos, al igual que las Formas imaginales (suwar hayäliyya), no están materialmente impresas, ni en el espejo ni en la imaginación. No, son "cuerpos en suspenso" (mu'allaqa) [...]. Tienen, por supuesto, lugares de aparición o lugares epifánicos (mazāhir), pero no están materialmente contenidos en ellos. El espejo es, desde luego, el lugar de aparición de las formas que vemos en el espejo, pero estas formas están a su vez "en suspenso"; no se encuentran en él ni como algo material en un lugar del espacio, ni como un accidente en su sustrato. La Imaginación activa (phantasis; tahayyul) es el lugar de aparición de las formas de la imaginación representativa (hay $\bar{a} l$ ), pero estas mismas formas están "en suspenso"»".

Este «mundo imaginal» constituye un «istmo» (barzah), un entre-dos o mundo intermedio entre lo material y lo espiritual, entre lo sensible y lo inteligible puro, entre el mundo de los cuerpos y el mundo de los espíritus: entre la geografía terrestre y la topografía espiritual, entre la ciudad de los sentidos que es Isfahān y la ciudad mítica de Hūrqalyā, Tierra-límite «mediana y mediadora» entre la belleza sensible de los azulejos y la luz verde brillante de la percepción visionaria. Corbin veía en la topografía de Irán la forma terrestre y sensible del mundus imaginalis. El oasis de Isfahān, la «ciudad azul», parece tipificar para nuestro autor el reflejo sensible de la ciudades míticas de esmeralda, a las que el viajero accede cuando ha alcanzado la montaña de Qāf:

«Hace todavía una treintena de años, al viajero que venía del sur por la ruta de Šīrāz, en un brusco viraje situado aún en la colina, Isfahān ofrecía a menudo la "visión de esmeralda" de sus jardines, sus "paraísos", de donde emergían, singulares, las propias cúpulas verdeantes de sus mezquitas y de

McGill University, Tehran Branch; Tehran University; The Imperial Iranian Academy of Philosophy, 1977, p. 31; id., Henry Corbin. La topographie spirituelle de l'Islam iranien, París: La Différence, 1990, pp. 23-4. (La cursiva es mía).

9 Cf. M. A. Razavi, «The Significance of the Suhrawardī's Persian Sufi Writings in the Philosophy of Illumination», en L. Lewisohn (ed.), Classical Persian Sufism: from its Origins to Rumi, Londres: Khaniqahi Nimatullahi Publ., 1993, pp. 259-83; id., Suhrawardī and the School of Illumination, Londres: Curzon, 1997, cap. 4: «Philosophical Sufism», pp. 78-120, esp. pp. 86-9.

10 Suhrawardī, Le Livre de la Sagesse Orientale (Kitāb hikmat al-išrāa), trad. y nn. de H. Corbin; intr. de Ch. Jambet, Lagrasse: Verdier, 1986 [1952], § 225, p. 199. Véase a su vez § 244, p. 213, § 247, p. 215. Cf. H. Ziai, Knoweledge and Illumination: A Study of Suhrawardī's "Hikmat al-Išrāq", Brown University Judaic Studies Series 97, Atlanta: Scholars Press, 1990. 
sus madrasah» ${ }^{11}$. Isfahān es para Corbin una ciudad emblemática: «Ir a Isfahān será ir a la Mezquita Real como lugar de encuentro entre el universo imaginal de Hūrqalyā, la más elevada de las "ciudades de esmeralda", y la maravilla arquitectónica percibida por los sentidos. Será también reencontrarse con la obra de los filósofos išrāquiyyūn cuya metafísica de la Imaginación permite este encuentro, puesto que ella nos abre al intermundo, intermediario entre lo inteligible puro y lo sensible» ${ }^{12}$.

\section{EL ESTANQUE COMO ESPEJO DE LO INTELIGIBLE}

Henry Corbin escribe que:

«La comparación a la cual recurren regularmente nuestros autores es el modo de aparición y de subsistencia de las Imágenes "suspendidas" en un espejo. La sustancia material del espejo, metal o mineral, no es la sustancia de la imagen, una sustancia cuya imagen sería un accidente. Ella es simplemente el "lugar de su aparición"»". En el Corpus Hermeticum podemos leer que «el cosmos sensible (aisthêtou) se refleja en el inteligible (noêtou), y el inteligible en el sensible» ${ }^{14}$.

La Imaginación activa es el espejo por excelencia, el lugar epifánico de las Imágenes del mundo arquetipo. El fenómeno del espejo, que está en el núcleo de la arquitectura persa de las mezquitas, funda igualmente la metafísica de la Imagen profesada por toda una línea de filósofos visionarios ${ }^{15}$. Hay también un vínculo interior entre las diferentes formas de la visión irania del mundo, una Gestalt de la cual se traza la epifanía tanto en la arquitectura como en el espacio cualitativo de las miniaturas. El concepto del espacio que determina la estructura de la mezquita iraní asegura la función esencial del Templo:

«Es un espejo de agua que refleja a la vez la cúpula celeste que es la verdadera bóveda del templum y los azulejos policromados que recubren las superficies.

11 Corbin, «Les cités emblématiques», o.c., p. 5.

12 Ib., p. 10. Sobre el sentido espiritual de esta ciudad véase también En Islam iranien, o.c., t. IV, pp. 9 ss.

13 H. Corbin, Face de Dieu, face de l'homme. Herméneutique et soufisme, París: Flammarion, 1983, p. 18.

14 Corpus Hermeticum, XVII. Se sugiere que uno ve las formas incorpóreas en los cuerpos del mismo modo que se ven las imágenes incorpóreas en los espejos. Para la analogía del espejo en Platón, véase Sofista 239d. Entre las diversas nociones del reflejo y la transfiguración véase 2 Cor 3:18, Flp 2:6-8, 3:21.

15 Cf. O. Grabar, «Isfahan as a Mirror of Persian Architecture», en R. Ettinghausen; E. Yarshater (eds.), Highlights of Persian Art, Boulder, Colorado: Westview Press, 1979, pp. 213-41. Véase a su vez O. Grabar, The great mosque of Isfahan, Londres: I. B. Tauris, 1990. 
[...] Todas sus imágenes son apariciones en un espejo, en la superficie espejeante de una pared o de la hoja de un libro» ${ }^{16}$.

Como ya he dicho hace un momento, Corbin era extremadamente sensible a la topografía de Irán, él veía en ella la forma terrestre y sensible del mundus imaginalis. Esto muestra lo que él mismo afirma de la mística de Rūzbihān Baqlī, que «es una metafísica que no se expresa en conceptos; se expresa esencialmente en imágenes [...] El pensamiento y las percepciones de Rūzbihān son esencialmente los de lo imaginal $[\ldots] »^{17}$.

El núcleo de este problema metafísico de la imagen especular se puede introducir a partir de un ejemplo extraído de la estética espiritual. El cosmos se estructura en una serie gradual de Presencias o Descensos que se corresponden con los diversos niveles de los seres y representan la relación entre Creador y criatura (Haqq y halq). Cada Presencia (hadra) o planos del ser a partir de la Ipseidad divina es la imagen y la correspondencia (mit $\bar{a} l$ ), el reflejo y el espejo de la inmediatamente superior, de tal modo que cada plano reproduce o imita, a la manera de un espejo y según su estructura específica, lo que existe en el inmediatamente superior. De este modo, todo lo que existe en el mundo sensible ('álam al-mulk, nāsūt) es un reflejo, una tipificación o modelo (mit $\underline{a} l)$ de lo que existe en el Mundo de los Espíritus ('âlam al-arwāh), y así sucesivamente hasta remontarnos a los primeros reflejos de la Esencia divina $(a l-d \bar{a} t)$, por lo que todo lo que se manifiesta ante los sentidos, es uno de los rostros (wağh) de Dios, es decir, de los Nombres divinos.

Es lo que proponen el plano del jardín iraní tradicional $(b \bar{a} g h)$ y el patio (hayāt) de la mezquita. La aplicación arquitectónica del concepto de jardín refleja el «sentido de lugar» (ma’kān), viéndose el jardín como un espacio definido que abarca dentro de sí mismo un reflejo total del $\operatorname{cosmos}^{18}$. Como exponente representativo podemos tomar el plano del estanque del extenso patio rectangular de cuatro $\bar{\imath} w \bar{a} n$-es y arcadas de cerámica policromada de la mezquita del Šāh (masğgid-i Šăh), así como el patio central de la madrasa Chahār Bāgh (madraseh-i mādar-i $\stackrel{S}{\bar{a} h}$ ), ambas en la ciudad de Isfahān. El estanque-espejo de Darb Yalon en la ciudad de Kāšān (en la provincia de Isfahān) es otro ejemplo del sentido simbólico de la superficie del agua del estanque verde esmeralda reflejando la Misericordia divina $(r a h m a)$.

16 Corbin, «Les cités emblématiques», o.c., p. 6.

17 H. Corbin (ed. per. e intr.), Commentaire sur les paradoxes des Soufis (Šarh-e Šathīyāt), Teherán; París: AdrienMaisonneuve (Bibl. Iranienne, $n^{\circ}$ 12), 1966, pp. 3-4.

$18 \mathrm{El}$ «sentido de lugar» $\left(m a^{\prime} k \bar{a} n\right)$ del jardín iraní tradicional $(b \bar{a} g h)$ y del estanque es el paradigma del jardín del Paraíso, cuyos planos se conciben como un mandala, como un reflejo total del cosmos. Cf. Ardalan; Bakhtiar, The Sense of Unity, pp. 34-5, 68; N. Ardalan, «The Paradise Garden Paradigm», en S. J. al-Dīn Āshtiyānī; H. Matsubara; T. Iwami; A. Matsumoto (eds.), Consciousness \& Reality: Studies in Memory of Toshihiko Izutsu, Leiden: E. J. Brill, 2000 [1998], pp. 112-9, esp. p. 112. 
Para entender el fenómeno del espejo ${ }^{19}$ se pueden poner dos ejemplos. El primero de ellos es el de los azulejos del $\bar{\imath} w a \bar{n}$ oeste (s. XIII) de la Mezquita del Viernes (maš̆ğd-i ğămi ${ }^{\circ}$ ), de época selyúcida (s. XI), que al reflejarse en el estanque polilobulado del patio adquieren un color verde: la ciudad azul de Isfahān transfigurada en la ciudad verde de Hūrqalyā. El segundo ejemplo es el del î̀eān occidental de la Mezquita Real (construida entre 1611 y 1629) reflectándose en el estanque del patio central ${ }^{20}$. En este último caso, la estructura de la mezquita polarizada por la doble axialidad del plano cruciforme presenta súbitamente un eje vertical, pasando por el centro del estanque y uniendo la tierra con el cielo por medio de la superficie del agua. El elemento vertical de la cruz está formado por el $\bar{\imath} w \bar{a} n$ mismo prolongado por su reflejo, mientras que el brazo horizontal de la cruz, de la misma anchura, está claramente dibujado por los dos niveles de arcadas laterales que se miran, ellas también, en el agua. Las cuatro direcciones cardinales (norte, sur, este, oeste) están indicadas por los cuatro ì wān-es que forman la planta cruciforme horizontal. El estanque-espejo introduce en cambio la dimensión vertical del nadir al cenit. Para el observador, este sistema de referencia espacial que son los ejes cruzados forma un todo, combinando la imagen real y la imagen virtual del reflejo. El estanque central impide al observador poder acceder al centro del patio. Pero ¿qué pasa cuando nos situamos en el eje de uno de los cuatro īwān-es? Nosotros lo contemplamos al mismo tiempo que su imagen invertida en el estanque. La bóveda celeste que se mira en el agua se transforma súbitamente en una esfera en el centro de la cual se halla el observador, percibiéndose a sí mismo en el corazón de la estructura ortogonal construida. Él es el centro de un espacio sin arriba ni abajo; él está en el hogar de una visión calidoscópica que simboliza el infinito de la creación. Esta imagen invertida es el resultado de la imagen virtual en el nivel de una catóptrica mística. Hacer pasar la imagen de la virtualidad a la realidad es realizar la operación misma que para los metafísicos de la Escuela de Suhrawardī significa la penetración en el mundus imaginalis ('älam al-mitāt), el "octavo clima" o mundo intermedio entre el mundo de la Idea pura y el mundo de la percepción sensible.

En el texto hermético de la Tabula smaragdina, cuya versión más antigua accesible en árabe se remonta al siglo VI, y que recoge el alquimista šcíi Ğābir ibn Hayyān en el siglo VIII, discípulo ferviente del VI imām, Ğa'far al-Ṣādiq, se halla la noción de espacio sin dirección y de microcosmo a imagen del macrocosmo que el reflejo del estanque muestra:

«En verdad, ciertamente y sin duda: Lo de abajo es igual a lo de arriba, y lo de arriba igual a lo de abajo, para obrar los milagros de una cosa única» ${ }^{21}$.

19 Stierlin, Ispahan, Image du Paradis, o.c., pp. 76-9, 176-8.

20 H. Stierlin ha sabido fotografiar y comentar este efecto en su libro Ispahan, Image du Paradis, o.c., pp. 28-9, 413, 97-9, 112-3, 154-5. Véanse a su vez, del mismo autor: Iran des bâtisseurs: 2500 ans d'architecture, Ginebra: Sigma, 197 ; Arte islámico: la influencia de la arquitectura persa desde Isfahán al Taj Mahal, Barcelona: Librería Universitaria de Barcelona, 2003.

21 J. Ruska, Tabula Smaragdina. Ein Beitrag zur Geschichte der hermetischen Literatur, Heidelberg: Carl Winter, 1926, I-II, p. 158. 
En el patio-sala infinito de la Mezquita Real, suspendido en la eternidad de un espacio de pura luz, las seis direcciones del espacio convergen como en un crisol en el que se mezclan la realidad y la virtualidad. Es al centro a donde remiten las grandes cavidades de los $\bar{\imath} w \bar{a} n$-es; es en él donde se condensa el espacio. Este centro es el lugar por excelencia: espacio trascendental, imagen de lo divino.

El fenómeno del espejo nos permite concebir la dimensión integral de una cosa o de un edificio situado en el espacio de este mundo, puesto que nos lleva a comprender la dimensión espiritual, la Imagen metafísica que precede y modela toda percepción empírica:

«Ver las cosas en el espejo, es según la expresión de uno de nuestros šayhs iraníes "ver las cosas en Hūrqalyā", la más elevada de las ciudades místicas del mundus imaginalis u octavo clima. El espejo no hace sino mostrarnos la vía para penetrar en Hūrqalyā. Fascinante es aquí la imagen del $\bar{\imath} w a \bar{n}$ oeste de la Mezquita Real iluminada por el sol naciente y mirándose en las aguas del estanque central» ${ }^{22}$.

Henry Corbin, hablando de la «aparición de los Invisibles», escribe:

«Es una búsqueda que se corresponde con lo que nos propone el plano del agua central del jardín ("paraíso") iraní tradicional, o bien el de la mezquita, por ejemplo el plano del agua central del vasto recinto de la Mezquita Real en Isfahān. El agua espejeante unifica la imagen de las inmensas superficies de loza azul esmaltada ( $k a s ̌ \grave{\imath})$ que la rodean; por la noche, le sucede una reunión de estrellas. Sumergirse en el estanque para "tocar" la imagen sería tan vano como romper el espejo. La superficie espejeante es el lugar de aparición (mazhar), pero la imagen no está allì» $^{23}$.

Encontramos aquí de nuevo dos nociones fundamentales de toda la gnosis islámica, las nociones de mazhar y de mazhariyya: forma de manifestación (la del espejo) y función epifánica de esta forma.

En apariencia, la superficie del estanque refleja tanto el cielo como el brillo iridiscente de los azulejos, en tanto que espejo de las formas del mundo sensible, de la inmanencia (tašbihh); pero al mismo tiempo el agua, con su leve movimiento, los unifica como epifanía del mundo manifestado ${ }^{24}$. Uno de los primeros místicos del islam, Ḥasan al-Baṣrī (m. 110/728), hombre docto que echó los cimientos de la «ciencia de los corazones» ( $i l m$ al-qulüb), compara el mundo en su relación con Dios con el reflejo

22 Corbin, «Les cités emblématiques», o.c., p. 7.

23 Corbin, En Islam iranien, o.c., t. I, pp. XXI-XXII.

24 El estanque del pabellón central, cuando se contempla dentro de la totalidad del patio, está configurado según la antigua iconografía de recapitulación del paraíso. Ese color de tonalidades en general azules, con su decoración de arabescos y frisos epigráficos, transforma la mezquita en paraíso por su belleza misma. 
que el sol proyecta en un plano de agua. Todo lo que podemos percibir de este reflejo proviene de su imagen original, pero ésta es independiente de su imagen reflejada e infinitamente superior a ésta. En el sufismo el agua es la gnosis, el corazón del fiel es su recipiente; el corazón (ár. qalb, per. dil) es la sede y la facultad de la gnosis o intuición mística (ma'rifa), pues el corazón-espejo del místico es el receptáculo (qābil) o «lugar de manifestación» (mazhar) de la divina Realidad (al-Haqq), la trascendencia $(\tan z \bar{\imath} h)^{25}$ de lo Absoluto. Rūmī afirma en este sentido: «nosotros éramos lisos y puros como el agua» ${ }^{26}$. La superficie del agua une así lo trascendente $(\operatorname{tanz} \bar{\imath} h)$ con lo inmanente $(\operatorname{tašb} b \bar{\imath} h)^{27}$, en un entredós que es el de la imaginación creadora, el de las «imágenes suspendidas».

Para llegar a esta Tierra de Hūrqalyā, la Tierra de las ciudades de esmeralda, se ha de producir una verdadera alquimia espiritual, consistente en ocultar lo aparente y manifestar lo oculto. A la Obra alquímica se la denomina también el «Espejo de los Sabios» (mir'ät al-hukamā'): «De la Obra del Elixir ('amal al-iksīr)», escribe el Šayh Ahmad Ahsā'̄̄, «los Sabios han hecho un espejo en el que contemplan todas las cosas de este mundo, tanto si se trata de una realidad concreta ('ayn) como de una realidad mental $\left(m a^{\prime} n a\right)$. La resurrección de los cuerpos aparece en este espejo como una analogía de la resurrección de los espíritus» ${ }^{28}$. Depositario de esta gran tradición mística, el Šayh Abū l-Qāsim Huān Ibrāhīmī (Sarkār Āgā), quinto sucesor del Šayh Ahmad, añade a propósito de esto:

«Respecto a la manera en que las almas hacen su entrada en este mundo, hay que compararla con la forma en que hace su aparición la imagen de la persona humana en el espejo que la refleja, e incluso con la luz del sol que, desde lo alto del cielo, cae sobre el espejo o la superficie de un agua tranquila. Ni la materia ni la forma de esta imagen que ves en el espejo proceden de la sustancia mineral de éste. No, esta imagen posee independientemente su propia materia y su propia forma, y así como éstas no proceden de la sustancia mineral del espejo, tampoco forman parte

25 El mundo imaginal media entre el tanzīh (lit. «alejamiento», «trascendencia», lo incomparable, la abstracción; fig. «carencia en Dios de atributos humanos») y el tašbīh (lit. «comparación, equiparación», la inmanencia, el antropomorfismo, semejanza, lo figural; fig. «alegoría, metáfora»). El único conocimiento posible de Dios, que favorecería su representación, consiste en maridar en un movimiento de oscilación el tanzīh y el tašbīh, la trascendencia y el antropomorfismo, la abstracción y lo figural. (Fus., p. 69). El escenario que acoge la experiencia de la visión en tanto que presencia (hadrat al-bașar) está también claramente gobernado por la polaridad de tanzīh/tašbīh. Cf. A. Meddeb, «L'icône mentale. Interdit de représentation et iconophilie en Islam: la question du figural et de l'abstraction telle qu'elle fut pensée par Ibn 'Arabī (1165-1240)», en A. Meddeb (dir.), Le paradoxe des représentations du divin, París: Dédale en Méditerranée, $\mathrm{n}^{\text {os }} 1$ \& 2, Maisonneuve \& Larose, otoño de 1995 .

26 Rūmī, Mathnawī, I:687.

27 Cf. Ardalan; Bakhtiar, The Sense of Unity, o.c., pp. 34-5 y 106; Ardalan, «The Paradise Garden Paradigm», o.c., p. 119 .

28 Hikma 'aršiyya, p. 165. Apud H. Corbin, Cuerpo espiritual y Tierra celeste. Del Irán mazdeísta al Irán chiíta, Madrid: Siruela, 1996 [1961], p. 122. 
de él de cualquier modo, ya que no tienen con esta última ni mezcla ni interferencia. Esta imagen tiene su propia existencia autónoma, fue creada aparte. Si el espejo está ahí, la imagen se proyecta en él y se "refleja". Si no está, no por ello deja de existir en sí misma y para sí misma; subsiste en su propio mundo, con su propia materia y su propia forma» ${ }^{29}$.

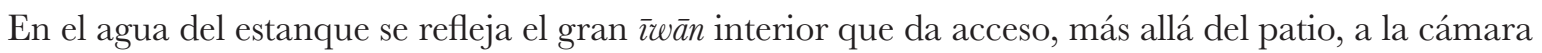
del mihrăb, y que tiene, él mismo, la forma de un magno nicho de oración: prefigura el mihrrāb sin duda alguna, pero a su vez adquiere un sentido ontológico como símbolo del nicho interior del «corazón» sutil ${ }^{30}$. El azul del cielo y el $\bar{\imath} w \bar{a} n$ espejean en el agua: el mundo de las imágenes y el mundo sensible se confunden en el espejo del estanque. El plano del suelo (taht) une así lo de arriba ('ulwar) con lo de abajo (suflù), el 'ālam al-mitāl (mundus imaginalis) con al-mulk (el «reino») o mundo visible ('älam al-šahāda), convirtiéndose así en un símbolo profundo de la gnosis islámica ${ }^{31}$. Se trata de una «Imagen unitiva» o mediadora entre el mundo de las puras realidades espirituales del universo del Misterio $(l \bar{a} h \bar{u} t)$ y el mundo visible y sensible $(n \bar{a} s \bar{u} t)$ que -según la teosofía de Suhrawardī y de Ibn al-'Arabī- hay que situar en la «presencia» o «dignidad imaginativa» (hadrat al-hayāl o hadrat al-mitāa), el mundo de las imágenes del malakūt inferior ${ }^{32}$. La superficie especular del agua es el lugar epifánico (mazhar), el receptáculo de las teofanías (tağalliy $\bar{a}$ ), la forma epifánica de la presencia divina (hadra) en el cosmos, tanto en lo referente al conjunto del mundo exterior cuanto respecto al mundo interior -la gruta

29 Texto extraído de Tanzīh al-awliyā’, Kirmān 1367/1948, pregunta 58, pp. 702-26; incluido en Corbin, Cuerpo espiritualy Tierra celeste, o.c., p. 266.

30 El ì îān o pórtico bajo el cual el sufí medita simboliza la vía (tarīqa), o el espacio de tránsito entre el mundo temporal y el mundo espiritual. Cf. Bakhtiar, Suf, o.c., p. 79. «En cierto sentido, el mihrāa es la puerta de lo invisible, y el $\bar{\imath} w a \bar{n}$ que se levanta frente a él es su faz, mientras que el pórtico de la mezquita compendia todo el santuario, pues la función de éste es precisamente la de puerta del más allá.» T. Burckhardt, El arte del Islam: Lenguaje y significado, Palma de Mallorca: José J. de Olañeta, 1988 [1976], p. 120.

31 Cf. Ardalan; Bakhtiar, The Sense of Unity, o.c., p. 35.

32 Véase S. Akkach, Cosmology and Architecture in Premodern Islam. An Architectural Reading of Mystical Ideas, Albany: State University of New York Press, 2005. Este fascinante estudio interdisciplinario revela las conexiones entre la arquitectura, la cosmología y el misticismo. Samer Akkach demuestra cómo el espacio ordenado en la arquitectura islámica premoderna refleja lo trascendente y lo sublime. El libro ofrece muchas traducciones nuevas, un número de fuentes inéditas y varias ilustraciones. Haciendo referencia a una amplia gama de textos místicos, y con especial énfasis en la obra del gran maestro sufí Ibn al-Arabī, Akkach introduce una noción de sensibilidad espacial que está conformada por las concepciones religiosas del tiempo y del espacio. Las creencias religiosas sobre el cosmos, la geografia, el cuerpo humano y las formas construidas son respaldadas por una consistente sensibilidad espacial anclada en el geocentrismo medieval. Dentro de este universo geométricamente definido y ordenado, nada se encuentra en aislamiento o ambigüedad; todo está interrelacionado y cuidadosamente posicionado en una intrincada jerarquía. A través de la cartografía detallada de este intrincado orden, este estudio muestra la importancia de este modo de ver el mundo para quienes vivieron en la época islámica premoderna y cómo las ideas cosmológicas se hicieron manifiestas en los edificios y espacios de la vida cotidiana. 
sagrada del corazón. Pero la imagen no se halla alli33 , pues si bien las formas aparecen en los espejos, no están sin embargo en ellos $^{34}$ : las imágenes vistas en los espejos, que no son ni objetos ni ideas abstractas, cumplen dicha función mediadora o simbólica.

Lo que nosotros llamamos physis y lo físico no es más que el reflejo del mundo del Alma. Un filósofo y teósofo contemporáneo de los monumentos safávidas que nos interesan, Muḥsin Fayḍ Kāšānī (m. 1091/1680), confirma la existencia de tales interpretaciones en el siglo XVII. Nuestro autor escribe que en este mundo de imágenes arquetípicas:

«[...] Los Espiritus toman cuerpo y los cuerpos se espiritualizan a través de ese mundo y en ese mundo de las Formas imaginales. [...] Más aún, la aparición de las figuras en los espejos o en cualquier otra materia capaz de reflejar, un agua limpia por ejemplo, se lleva cabo asimismo en ese mundo intermedio, ya que todas las figuras que reflejan los espejos pertenecen también a ese mundo. Es más, todas las formas y figuras inmanentes a nuestra Imaginación activa, tanto si se trata de un sueño como de un estado de vigilia, se ven en ese mundo intermedio, ya que estas formas y figuras son contiguas a ese mundus imaginalis; reciben su luz como si fueran lucernas y rejas a través de las cuales penetra el rayo de luz en una morada» ${ }^{35}$.

El plano espejeante del estanque expresa la teofanía (tağallî̀) en sus múltiples modalidades. Ibn al-'Arabī contemplaba también el proceso de despliegue de la Multiplicidad a partir de la Unicidad como una sucesión ininterrumpida y perpetua de teofanías (tağalliyāt) que se renuevan continuamente. Pues el agua que tiene el color de la copa que la contiene, o bien la gota - que es la fluctuación del corazón del hombre- en el Océano -la eterna quietud de la Existencia de Dios (wuǧŭd)- son símbolos de la mística del reflejo, imágenes del hombre como espejo epifánico de lo Invisible. El agua límpida del estanque situado frente al mausoleo de Ni'matullāh Walī refleja los fenómenos múltiples de la existencia y los

33 Cf. Corbin, En Islam iranien, o.c., t. I, pp. XXI-XXII.

34 Según Ibn al-Aarabī, cuando se ve una imagen reflejada en un espejo, en ver el cuerpo del espejo no ves el reflejo: «Lo mismo acontece con el espejo en nuestra realidad más inmediata: cuando ves una imagen reflejada en él, no ves el espejo aunque sepas a ciencia cierta que no distingues esa imagen, o tu imagen, más que sobre la superficie de su cuerpo. Allāh te brinda esta alegoría para su tajallī desde la Identidad, para que aquél al que Él mismo se ofrece, sepa que no Le ha visto. No hay otro ejemplo más próximo y explícito que el de la visión del espejo y el reflejo. Intenta esforzarte, cuando veas una imagen reflejada en un espejo, en ver el cuerpo del espejo: no lo verás nunca en absoluto. [...] La imagen visible se sitúa entre la vista del que mira y el cuerpo del espejo, interponiéndose: hasta ahí llega su conocimiento. [...] No ambiciones más ni te agobies intentando escalar por encima de este escalón, pues ahí no está Él en absoluto, y después no queda más que la nada en su estado de pura simplicidad.» Fus., cap. sobre Šìth (Seth). Cf. Los engarces de la sabiduría (Fușūs al-hikam), trad. de A. M. Maanán, Madrid: Hiperión, 1991, pp. 19-20; Corbin, La imaginación creadora, p. 253.

35 Tomado de Kalimāt maknūna (Palabras mantenidas en secreto), Bombay 1296 H., cap. XXXI, pp. 69-72; Teherán 1316 H., pp. 68-70; incluido en Corbin, Cuerpo espiritual y Tierra celeste, o.c., pp. 202-3. 
unifica en el plano del agua como una única imagen-tapiz: símbolo de la «unicidad de la existencia». Como poeta, Ni'matullāh Walì canta, de forma incansable y bajo mil formas, la mística del reflejo como manifestación del Uno (al-ahad), pues más allá de los colores y formas reflejadas en el agua está el cielo abierto que los diluye como imagen de la Unicidad divina.

El espejo, espacio vacío revitalizado únicamente por medio de la luz, es la dimensión ulterior en que toman vida las formas del mundo en el espacio imaginario intermedio, barzahñ, en toda su pureza y en su dimensión intemporal y trascendente. El espejo es capaz de recibir el universo entero de las formas permaneciendo siempre idéntico a sí mismo. La utopía del sufismo se nos ofrece, por tanto, como la superficie pulida en la que se encarna la pureza absoluta de todas las formas posibles en la frontera entre la divinidad y la naturaleza. Equivale, aunque limitado por su pasividad, a la función del alma y de la Imaginación (hay $\bar{a} l$ y la luz que las ilumina, donde se comprende y se percibe la infinita unidad y variedad simultáneas existentes entre las formas del mundo y el Verdadero (al-Haqq).

La superficie del estanque de la mezquita representa la fusión de lo sensible y lo inteligible en el puro espacio del mundus imaginalis ('âlam al-mitāl): es simultáneamente materia inmaterial e incorporeidad corporizada en cuerpo sutil. Sólo en relación a esta capacidad visionaria del alma (por medio del sueño visionario, la meditación contemplativa «imaginadora»...) se puede entender el fenómeno del espejo. Lo que el hombre espiritual ve ante sí es la proyección del mundo imaginal ('ālam al-mitāā), el mundo del malakūt (el mundo del Alma y de las almas), sobre el mundo sensible ('âlam hissšl), el «reino» (mulk) de las cosas materiales: i.e. la aparición de las Formas imaginales (suwar mitäliyyya) que la función imaginadora del órgano sutil del alma es capaz de percibir manifestándose como siluetas o sombras en la belleza de las Formas sensibles (suwar hissiyya) del propio santuario (la bóveda, el estanque, los reflejos del agua...). El mundo del barzah (pantalla, límite, intervalo, intermundo) ${ }^{36}$, mundo que tiene su existencia en sí mismo, constituye así el límite que las separa y que al mismo tiempo las une ${ }^{37}$. Gracias a su situación mediana y mediadora entre el ğabarūt, el mundo de las puras Inteligencias o

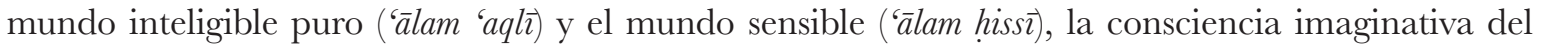
gnóstico recibe a través del malakūt las manifestaciones del mundo divino.

Más allá de la imagen sensible está la Imagen en su realidad absoluta, es decir, liberada, separada, del espejo sensible en el que se refleja; esta imagen real se percibe por medio del sensorium del ojo interior o visión interior, la visión del corazón:

«Esto quiere decir que del mismo modo que la sustancia material y la forma del espejo no son ni la materia ni la forma de la Imagen que se refleja en él y se percibe en él, sino tan sólo el lugar privilegiado en el que

$36 \mathrm{Al}$-barzah, «el istmo», es el universo observado entre los mundos de entidades sin forma (ma $\bar{a} n \vec{\imath})$ y el mundo de los cuerpos. Cf. Ibn al-'Arabī, Istitiāhāt al-sūfiyya, en Rasā’il; versión ampliada en Fut. II: 128-134. Véase a su vez Dā'ūd Qayșarī, Comentario de los Fus. de Ibn al-'Arabī, Bombay, 1299.

37 Cf. Corbin, Cuerpo espiritual y Tierra celeste, o.c., pp. 9 ss., 103 ss. 
se epifaniza esta Imagen, así también las materias sensibles no son más que el vehículo (markab), o mejor aún, el lugar epifánico (mažhar) para las formas que produce la actividad absoluta del alma. Considerar que el espejo constituye la sustancia y la consistencia de las Imágenes que aparecen en él sería un grave error. El espejo puede cambiar de lugar, puede romperse, pero las formas del alma, al no ser inherentes ni consustanciales al espejo, siguen subsistiendo» ${ }^{38}$.

Pero el espejo por excelencia es el propio corazón esmerilado del gnóstico. Según el conocido pasaje de los Fușus al-hikam de Ibn al-'Arabì:

«Aquél a quien Él se epifaniza no ve nada más que su propia forma en el espejo de la Realidad divina (al-Haqq); no ve la Realidad divina y no puede verla, aunque sepa que es en Ella donde ha percibido su propia forma [...]. Él (Dios) es, pues, tu espejo donde te contemplas; y tú eres Su espejo donde Él contempla Sus Nombres» ${ }^{39}$.

La bóveda invertida de la mezquita, reflejada sobre el plano del agua, simboliza el nicho espejeante de luz que es el propio espejo del corazón (mir'āt al-qalb), receptáculo de la manifestación divina en el que se cumple que Dios es tu espejo donde te contemplas. Utilizando el simbolismo del espejo, validado por un hadiz: el hombre es un espejo donde aparece el reflejo invertido de la Realidad divina (Haqq). Lo que es bātin («oculto») en Dios, es zăhir («aparente») en el hombre. Por ello Ibn al-Arabī afirma con fuerza en las Futūhāt:

«Tú eres Su reflejo invertido! ¡Tú eres Su corazón y Él es tu corazón! (Fa-anta maqlūbu-hu! Fa-anta qalbu-hu! Wa-huwa qalbu-ka!) $»^{40}$

Según Ibn al-Arabī, cuando el velo (hiǧăab) se alza ${ }^{41}$, en el estado de desvelamiento $(k a s ̌ f f)^{42}$, el corazón

38 H. Corbin, Cuerpo espiritual..., p. 106.

39 Fus. I, pp. 61 ss.; Fut. I:163; IV:2. Véase M. Chodkiewicz, Un océan sans rivage: Ibn Arabi, le Livre et la Loi, París: Seuil, 1992, pp. 61-2.

40 pud M. Chodkiewicz, «El Corán en la obra de Ibn 'Arabī», en A. Carmona González (ed.), Los dos Horizontes (Textos sobre Ibn Arabī), Murcia: Editorial Regional de Murcia, pp. 137-8. La idea del hombre (al-insān al-kāmil) como espejo de Dios y de Dios como espejo del hombre está desarrollada en el primer y en el segundo de los capítulos de los Fusūṣ (véase en particular I: 53 y 61 ss.). Está igualmente evocada en las Futūhāt (I: 163; IV: 430, etc.).

41 Según Ibn al-Arabī, aunque los pecadores alcanzarán la felicidad en el Fuego, un factor sigue diferenciando su felicidad de la de los habitantes del Jardín: siempre habrá un velo (mahğūb) entre ellos y Dios, mientras que a los dichosos del Jardín se les concederá una visión (ru’ya) de Él. De aquí que el Šayh pueda escribir: «El otro mundo tiene dos moradas: la visión y el velo» (Fut. II 335:18). «El fin es la dicha, y ha sido alcanzada con el velo, pero ¿Dicha para quién? ¿Cómo puede compararse la dicha de la visión de Dios con la dicha del velo? Pues en ese día un velo a todos les impide ver a su Señor (83:15).» (Fut. III 119:7).

$42 \mathrm{El}$ significado literal de la palabra kašf es desaparecer o caer el velo. En la terminología sufí se refiere al 
del gnóstico es como un espejo en el que se refleja la forma microcósmica del Ser divino ${ }^{43}$ :

«[...] Gracias a la Imaginación activa, el corazón del gnóstico proyecta lo que se encuentra reflejado en él (aquello de lo que él es espejo), y el objeto sobre el que así concentra su fuerza creadora, su meditación imaginadora, hace su aparición en tanto realidad exterior, extramental. [...] Si el corazón es el espejo en el que el Ser divino manifiesta su forma según la capacidad de ese corazón, la Imagen que éste proyecta es, a su vez, la exteriorización, la "objetivación" de esa Imagen. Ahí encontramos la confirmación de que el corazón del gnóstico es el "ojo” por el que Dios se revela a sí mismo»" El Amado está oculto por la fuerza y la abundancia de su propia revelación. Todo lo que existe es pues a la vez espejo y velo de Su Rostro.

\section{LA «GÚPULA MINIADA» AZUL}

Analizando la gama de los nombres de color, Louis Massignon afirmaba que éstos son generalmente de origen persa: «[...] Tenemos la palabra "azur" que viene de läğward [...]; en cuanto al color azul es el triunfo de la belleza irania puesto que tenemos no sé cuántos azules. La gama de azules en las bóvedas, en las cúpulas y en los casimires es verdaderamente admirable, especialmente en la época del Šayh Bedran y de Sultaniyé. Desde el siglo IX, en Bagdad, el vocabulario técnico de los árabes empleaba asmāngūñ , es decir, color del cielo, para designar el azul claro» ${ }^{45}$. Se ha dicho que «el arte del encaje de ladrillo (en Irán) debe su reaparición al entusiasmo mesiánico del š̄íśsmo de los doce imāmes» ${ }^{46}$. Aunque esta afirmación parece algo excesiva a primera vista, no obstante hay que recordar aquí que los autores árabes en el siglo X citan ejemplos de edificios con cúpulas de color verde o turquesa en Bagdad y de Bujara, lo que puede indicar que se trata de lugares de culto šŕíes, pues como se sabe el verde es el color de los 'Alíes (descendientes de 'Alī y de Fātịma, entre los cuales

descubrimiento de las realidades espirituales y las verdades invisibles y ocultas más allá del velo. Para Rūzbihān Baqlī Šīrāzì: «Kašf es el desvelamiento de lo que está velado a la comprensión intelectual». Mukāšafa es el «descubrimiento» o aparición de lo que está detrás del velo. Rūzbihān piensa que cuando el Velo se ha vuelto espejo, la prueba ha sido superada. Cf. Rūzbihān, Commentaire sur les paradoxes des soufis (Sharh-e Shathīyatt), p. 557.

43 Sobre el motivo del espejo en la obra de Ibn al-Arabī véanse: S. Hakim, «Unity of Being in Ibn 'Arabī: A Humanist Perspective», JMIAS 36, (2004), pp. 25-7; J. W. Morris, The Reflective Heart: Discovering Spiritual Intelligence in Ibn Arabi's Meccan Illuminations, Louisville, KY: Fons Vitae, 2005, s.v. «mirror».

44 Sobre el motivo del espejo en la obra de Ibn al-Arabī véanse: S. Hakim, «Unity of Being in Ibn 'Arabī: A Humanist Perspective», FMIAS 36, (2004), pp. 25-7; J. W. Morris, The Reflective Heart: Discovering Spiritual Intelligence in Ibn Arabi's Meccan Illuminations, Louisville, KY: Fons Vitae, 2005, s.v. «mirror».

45 L. Massignon, «Valeur culturelle internationale de la coopération des penseurs Iraniens du Moyen Âge à l'essor de la civilisation arabe» (1951), incluido en Opera minora, o.c., t. I, p. 544.

46 Véase A. Mazaheri, Los tesoros de Persia, Ginebra: Skira; Destino, 1970, pp. 221 ss. 
se encuentran los imāmes šícies). El principal objeto de devoción en un mausoleo šící es el sanduq, la lápida sepulcral, verdadero altar adornado con inscripciones. Para los fieles, el contacto con esta lápida significa una posibilidad de curación en este mundo y una garantía de salvación en el otro. Los más antiguos revestimientos de azulejos se hallan en los sanduq-s de ciertos mausoleos de los imāmes, como el de Fāṭima, la hermana de 'Alī al-Riḍā, el VIII imām, sito en la ciudad santa de Qumm, cuyos colores son plateado, azul y marrón, pero las inscripciones están hechas con letras de oro; o bien el mausoleo del propio imām al-Riḍā, que se encuentra en Mašhad, que está adornado también con un bello revestimiento de azulejos azul y oro.

Una tradición afirma que la tierra de Irán es el país «color del cielo» (per. āsmān-gūn), color celeste, puesto que con las primeras luces del día los azulejos de sus santuarios-de color turquesa $(\text { fruze } \imath)^{47}$, azul celeste lapislázuli (lāğward-i ābginnih $)^{48}$ u otra piedra azul-, se confunde en las alturas con el azul del cielo. Esta idea de la luz matinal nos hace pensar en la aurora consurgens de la sabiduría oriental de Suhrawardī. Así lo constató Henry Corbin ante el mencionado santuario de Fāṭima:

«Quizás se presentirá el secreto de la ciudad de Qumm si con los primeros resplandores del sol matinal se ha podido contemplar la inmensa fachada del prestigioso santuario, levantando con seguridad el azulejo de su revestimiento cuyo azul profundo se confunde en las alturas con el azul del cielo. Entonces, te viene a la memoria la calificación de la tierra de Irán

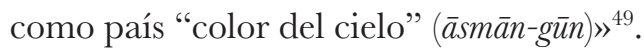

En los poemas épicos de Farīd al-Dīn 'Aț̣ār (m. 618/1221), el gran poeta sufí, son recurrentes los diálogos entre el Océano sin fondo y el peregrino, es decir, el alma que alcanza el océano de su ego, lugar donde el alma y Dios finalmente se han unido. En El Libro de la prueba (Mușībat-nāma) el océano se desencadena, lanza olas y espuma, y es todo entero fuego y sangre. En la obra de 'Atțār el viajero encuentra el océano en él mismo y llega al punto en el que la vía hacia Dios se detiene, donde comienza el viaje en Dios. En estos diálogos aparece la referencia al simbolismo del sufí vestido de azul cuyo corazón está lleno de perlas. 'Atṭār sabe que la gota necesita años antes de convertirse en perla límpida en el fondo del océano, que tormentos sin fin le esperan en la vía:

47 En realidad, los colores azul y turquesa, que son los propios de los mihrab-s y los sanduq-s, como de los revestimientos de las cúpulas enteras, tienen un valor de talismán: es el «arquetipo de la Vida», tal como los caracteriza C. G. Jung (cf. Les Métamorphoses de l'Âme et ses Symboles, Ginebra, 1953).

48 Cf. Y. Porter, Peinture et arts du livre. Essai sur la littérature technique indo-persane, París; Teherán: IFRI; Peeters, 1992, pp. 86-92. Sobre el simbolismo del color en la arquitectura islámica véase M. Barry, Fä̈ences d'azur, París: Imprimerie nationale, 1995.

49 Corbin, En Islam iranien, o.c., t. IV, p. 125. 
«El peregrino llegó ante el Océano sin fondo y dijo: “iOh tú, ebrio muerto de pasión por Él! Las olas de tu amor se han desencadenado; tu ardor y tu deseo vacilan de un extremo a otro. ¡Has bebido agua y no obstante estás sediento, chorreas agua y sin embargo tienes los labios secos! ¡Toda esta agua absorbida no te basta; si hiciera falta, contendrías más! ¡En audacia eres inextinguible; sé magnánimo puesto que tú eres el que lo arriesga todo! Sufí vestido de azul, tú eres también amante y tu corazón está lleno de perlas. ¡Ah, si no hubiera en ti esta efervescencia, tú serías en azulados un diamante cortado como la espada! ¡Sufí vestido de zafiro, joyero, borbotea, pues en tu espuma se multiplican las perlas! ¡Tú te embriagas de fervor y lo que buscas, lo tienes! ¡Mira mis ojos, nubes de lágrimas de sangre; muéstrame una señal del Incognoscible, por pequeña que sea!» ${ }^{50}$

Esta idea de los vestidos de azul va asociada a los sufies que caminan en la difícil vía hacia el Océano divino, tal como 'Atțār explica en otro bello poema épico, El lenguaje de los pájaros (Mantiq al-tayr):

«Un observador de las cosas espirituales fue junto al Océano y le preguntó por qué iba vestido de azul; el porqué de la ropa de duelo y por qué borboteaba sin fuego.

El Océano dio esta respuesta a este hombre de espíritu atento:

"Estoy conmovido a causa de la separación de mi amigo. Como que, debido a mi insuficiencia, yo no soy digno de él, me he puesto ropas azules como muestra de la tristeza que siento. En mi turbación mis labios se han secado, y a causa del fuego de mi amor experimento esta agitación similar a la ebullición. Si pudiera encontrar una gota de su agua celeste del Kawtarar, yo gozaría en su puerta de la vida eterna. Sin esta gota que busco moriría de deseo con los miles de individuos que perecen día y noche en su vía» ${ }^{52}$.

El gran maestro kubrawí Nağm al-Dīn al-Kubrà (m. 618/1221), en su tratado en persa titulado

50 Farīd al-Dīn 'Aț̣ār, Le Livre de l'épreuve (Musībat-nāma), trad. del per. de I. de Gastines, París: Fayard, 1981, cap. XX, p. 159. Sobre el sufí vestido de azul véase a su vez el cap. XIII. Cf. H. Ritter, Das Meer der Seele. Mensch, Welt und Gott in den Geschichten des Farīduddīn Attār, 2a ed., Leiden: E. J. Brill, 1978 [1955], pp. 514-5.

51 Fuente o río de abundancia del paraíso. Alusión a Cor. 20:12.

52 Farīd al-Dīn 'Attār, Mantic Uttaïr ou Le langage des oiseaux (Mantiq al-tayr), trad. del per. de M. Garcin de Tassy, Plan de la Tour (Var): Éditions d'Aujourd'hui, 1975, cap. X, p. 54. 
en árabe $\bar{A} d a b$ al-șüfiyya (Las buenas maneras de los sufies) ${ }^{53}$, explica la costumbre de cambiar el color «litúrgico» del manto místico en función de los progresos de la vía espiritual. Según afirma en su diarium spirituale, titulado Fawā'ị al-ğamāl wa-fawātih al-ğalāl (Las eclosiones de la Belleza y los perfumes de la Majestad $)^{54}$, el color azul oscuro $(k a b \bar{u} d)$ o violeta es el color del alma sensual, símbolo del yo inferior (al-nafs al-ammāra), la sombra que impide ver tu testigo celestial. En Las buenas maneras de los sufies sostiene que el manto de color negro y azul es el signo de la victoria sobre el alma carnal, el símbolo de la mortificación ${ }^{55}$. Por ello la indumentaria sufi de este color (murakka'a), conforme a la significación del color azul en la obra de al-Kubrà y al-Simnānī, simboliza las primeras etapas de la vida mística ${ }^{56}$; la

53 Nağm al-Dīn Kubrà, Ādāb al-sūffyya, ed. de M. Qāsimī, Teherán: Kitābfurūšì-yi Zawwār, 1363/1984. Véase la traducción en Najm al-Dīn Kubrā, La pratique du soufisme: quatorze petits traités, trad. del ár. y del per. y pres. de P. Ballanfat, Nīmes: Éditons de l'Éclat, 2002, pp. 147-64.

54 F. Meier (ed. en ár. y coment.), Die Fawā'ih al-jamāl wa-fawātih al-jalāl des Najm ad-dīn al-Kubrā. Eine Darstellung mystischer Erfahrungen im Islam aus der Zeit um 1200 n. Chr., Wiesbaden: Franz Steiner, 1957; trad. franc.: Najm al-Dīn Kubrā, Les éclosions de la beauté et les parfums de la majesté, trad. del ár. y pres. P. Ballanfat, Nìmes: Éditions de l'Éclat, 2001.

55 Las buenas maneras de los sufies, § 9. Al-Kubrà afirma en su tratado Los consejos para la élite (Nasīha al-hawāss), ms. Shehit Ali 2800, fols. 4la-47a, § 8: «A consecuencia de ello este vestido azul o rayado es el vestido de la humildad y del servicio, y quienquiera que lo lleve recibe la bendición. Y estos vestidos rayados el Amado los ha verdaderamente amado. Y también se da el hecho de que como estos vestidos se han convertido en la manera de vestir de los virtuosos, se los cuenta entre numerosas obras según la regla de la costumbre y del hábito.» Incluido en La pratique du soufisme, o.c., p. 236. Véase también el Libro de los buenos usos del itinerario hacia la presencia... (Kitā̄b ādāb al-sulūk ilà hadra mālik al-mulk wa-malik al-mulūk), ms. Bibl. Malek de Teherán, $n^{\circ}$ 4034, § 3, incluido en $i b$. p. 263.

56 De ahí que en estas cofradías se reciba la investidura del hábito hecho de harapos (hirqa) del mismo color que las luces coloreadas visualizadas, propias del grado místico que el derviche ha alcanzado. Se les llama hombres «vestidos de azul» (per. kabüd-pušăn), para indicar así los primeros grados de avance espiritual que el místico ha logrado. Kabüd-pušăn es en persa una denominación corriente de los sufies que se refiere a su costumbre de llevar ropas de color azul; se han dado diversas explicaciones de este uso. La hirqa era habitualmente de color azul oscuro. Era práctica para el viajero puesto que en este color la suciedad no era fácilmente visible, y al mismo tiempo era el color del duelo y de la pobreza mística. Aquí, la utilización de vestiduras azules adquiere un significado preciso, que se ajusta a un simbolismo general del color de la ropa. Conforme al significado del color azul (tanto en Nağm Kubrà como en Simnānī), el uso de ropas de este color conviene a aquellos que están todavía en las primeras etapas de la vía mística. Así se comprende la ironía de Haāiz respecto de aquellos sufies que hacían del uso de ropas de este color una costumbre constante: ise trataría de personas que no habían superado nunca las etapas iniciales? Por el contrario, cuando el gran poeta místico de Šìrāz destacaba la posición de su maestro, el Šayh Maḥmūd 'Aț̣āa de Šîrāz, conocido con el sobrenombre de «maestro color de rosa» (per. pìr-i gulrang) con respecto a los «vestidos de azul», hace alusión a esta costumbre de cambiar el «color litúrgico» de la indumentaria personal en función de los progresos en la vía espiritual. Comparar el comentario turco de Sūdī (II.42) que expone el ta’̌ñl de este hemistiquio de Ḥāfiz: «Mi "maestro color de rosa" a los ojos

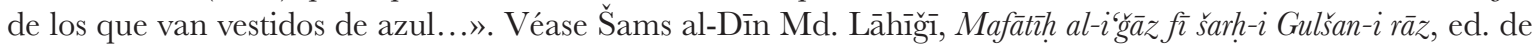
K. Samīīi, Teherán, 1337 h.s., p. 84 del pref. Para el color azul de la muraqqa'a llevada por los sufies, véase O. Pretzl, «Die Streitschrift des Ghazālī gegen die Ibāhīya», Sitz. Ber. Bayr. Ak. d. Wiss. phil. hist. Abt. Jg., 7 (1933), p. 12 n.; T. Andrae, Die Person Muhammads in Lehre und Glauben seiner Gemeinde, Estocolmo, 1918, p. 298; Rūzbihān Baqlī Šìrāzì, Le Jasmin des Fidèles d'amour (Kitāb-e Abhar al-'āšriqūn), ed., intr. y trad. del primer cap. M. Mo'in y H. Corbin, Teherán; París: DIIFI; Adrien Maisonneuve, 1958, (Bibl. Iranienne, 8), p. 57 de la intr., n. 108; p. 62, 
intención era mostrar que el sufí se había retirado del mundo y de lo que éste comportaba. Nağm alDīn Kubrà distingue dos categorías de color azul: kabūd (azul profundo) y azraq (azul cielo) ${ }^{57}$.

Tras un combate espiritual que permite el triunfo sobre la psique inferior (al-nafs al-ammāra), se puede acceder a una etapa más elevada, una morada espiritual superior en la que por medio de la concentración de su energía espiritual (himma) el místico accede a los mundos translunares, que nuestros autor indica por medio del porte de vestimentas de color azul celeste. Así pues el iniciado debe llevar la ropa del color correspondiente a su estado interior, afirmando que el manto azul color del cielo $(\bar{a} s m \bar{a} n-g \bar{u} n)$ es la señal de que el adepto ha alcanzado el mundo superior por medio de la concentración visionaria o energía espiritual. No obstante,

«Si, por medio de la concentración visionaria, [el sufí] ha rebasado el mundo inferior y ha alcanzado el mundo superior, si se ha convertido en el cielo de la concentración visionaria y la estrella de la belleza, que se vista con el manto azul, que tiene el color del cielo. Si ha pasado por todas las etapas y moradas, si por cada una ha adquirido una parte, y si una eclosión de luz le ha iluminado a partir de las luces de los estados espirituales, que lleve un vestido multicolor $r^{58}{ }^{59}$.

1. 13 del texto; H. Corbin, El hombre de luz en el sufismo iranio, Madrid: Siruela, 2000, pp. 168-9, n. 123; L'Archange empourpré. Quinze traités et récits mystiques de Sohravardī, trad. del per. y del ár., pres. y nn. de H. Corbin, París: Fayard, 1976, Āwāz-i parr-i Gibrā'̄ll (El murmullo de las alas de Gabriel), pp. 227, 257, n. 2; Risāla fì hālat al-tufüliyya (La epístola sobre el estado de infancia), pp. 406, 412, n. 44; En islam iranien, o.c., t. IV, pp. 342-3.

57 Cf. el texto de sus $\bar{A} d \bar{a} b$ al-murīdīn, citado por F. Meier, Fawä’ih, p. 126, n. 7: se llevarán vestidos de color negro $(s i \bar{y} h)$ y azul $(k a b \bar{u} d)$ cuando el combate espiritual haya permitido el triunfo sobre la psique inferior (al-nafs al-ammāra), como si se llevara luto por ésta. El significado no es pues el mismo que en el caso de Lāhīḡị; no se trata aquí de la etapa superior en la que se habla de «luz negra». En una morada espiritual superior, aquella en la que por la concentración de su energía espiritual (himma) el místico accede a los mundos translunares, Nağm al-Dīn Kubrà indica el uso de vestidos de color azul celeste. De todas maneras, es preciso tener en cuenta la escala simbólica de los colores, que puede variar, de un maestro al otro, o incluso, tal como se comprueba aquí con al-Kubrà, en obras diferentes de un mismo autor.

$58 \mathrm{El}$ manto multicolor, o para ser más precisos, «el manto de mil colores» (per. hirqa-yi hazār mīhñ), es el signo del santo realizado que ha atravesado todos los estados espirituales y ha sacado un provecho de ello. Sobre este punto véase el conjunto de textos kubrawíes reunidos por M. T. Dānishpazhūh, «Ḩirqa-yi hazār mīkhī», en M. Mohaghegh; H. Landolt (eds.), Collected Papers on Islamic Philosophy and Mysticism, Teherán: Tehran University Publ.; McGill University Institute of Islamic Studies (Montreal), Teherán, 1971, pp. 147-90; véase también Correspondance spirituelle échangée entre Nūroddīn Esfarāyeñ̄ (ob. 717/1317) et son disciple Alāoddawleh Semnān̄̄ (ob. 736/1336) (Mukātabāt-i Abd al-Rahmān Isfarāyiñ̄ bā Alā' al-Dawla-yi Simnāñ̄), ed., intr. y nn. de H. Landolt, Teherán; París: DIIFI; IFRI; A. Maisonneuve (Bibl. Iranienne, no 21), 1972, pp. 45-7; J. J. Elias, The Throne Carrier of God. The Life and Thought of 'Alā' ad-dawla as-Simnān̄, Albany: State University of New York Press, 1995, p. 41, n. 24.

59 Las buenas maneras de los sufies, § 9. (La cursiva es mía). 
A distancia y desde las alturas, las bellas cúpulas azul turquesa de Isfahān, de los santuarios de Māhān, Šīrāz o Mašhad, parecen el oasis verde de la Fuente de la Vida eterna sobre la tierra, el reflejo especular del mundo imaginal, de la Tierra paradisíaca. La mezquita representa pues un «superjardín» destinado a simbolizar materialmente el Paraíso (gr. parádeisos, per. firdaws) ${ }^{60}$, en el Avesta pairidaêza, según la descripción misma que dan del Edén las suras del Corán (55:46-76): «dos jardines... oscurísimos por lo frondoso de su vegetación» (55:62-64) ${ }^{61}$. Las concepciones iranias pre-islámicas confirman la importancia del color verde y le otorgan una significación muy determinada. Antaño, los partos habían introducido la bóveda y los sasánidas la cúpula. Eran cúpulas verdes, según nos informa el escritor al-Ǧāhị de Basora (m. en 868), pues para el iranio el verde era el color simbólico del cielo ${ }^{62}$. Las mezquitas de Bagdad y de Bujara, citadas por los autores árabes del siglo X, con sus cúpulas verdes, no serían más que los herederos. En cuanto a los edificios de Isfahān, construidos bajo Šāh 'Abbās y sus sucesores safávidas, son los descendientes directos de esta venerable línea de monumentos consagrados al culto, en el mundo iranio. Según la arquitectura simbólica islámica, la cúpula (per. gunbad), como arquetipo de la bóveda celeste, constituye el locus del Trono divino (al'ars $)^{63}$. A su vez el patio de las mezquitas safávidas simboliza el Paraíso ${ }^{64}$, según el versículo coránico (66:1 1): «iSeñor mío! ¡Constrúyeme, en el Paraíso, una casa junto a Ti!» ${ }^{65}$.

60 Cf. Schimmel, «The Celestial Garden in Islam», o.c., pp. 13-39.

61 Respecto al color verde, en Cor. 55:64, verdinegros se refiere a la coloración producto de un riego abundante. 62 Mazaheri, Los tesoros de Persia, o.c., p. 172. «El artista iranio considera que el color no es el aspecto físico del objeto, como era el caso de los griegos, sino su atributo metafísico. [...] Para el iranio, el azul, el blanco, el verde y el rojo son respectivamente los símbolos del cielo, del huevo, del árbol y del fuego, y no sus atributos físicos, cualidades pasivas según Aristóteles.» Ib., «Los colores de Persia», pp. 108-13, p. 108.

63 A propósito de la aleya 65:12: «Dios es quien ha creado siete cielos y otras tantas tierras», el 8º imām, 'Alī al-Riḍā (203/817), enseña en un largo hadiz en el que hace referencia a las Tierras y Cielos en estado de Formas imaginales: «Esta tierra es la tierra [malakütī] del mundo de abajo, y los cielos del mundo inferior forman por encima de ella una cúpula. La segunda Tierra está por encima del cielo de este mundo inferior [es decir, por encima de la cúpula del mundo visible de los sentidos], y el segundo cielo forma por encima de ella una cúpula. La tercera Tierra está por encima del segundo cielo, y el tercer cielo forma por encima de ella una cúpula.» Y así de forma sucesiva hasta llegar a la séptima Tierra que está por encima del sexto cielo, mientras que el séptimo cielo (kursī, el firmamento) forma por encima de ella una cúpula. «Y el Trono de la Misericordia ('arš al-rahma) está por encima del séptimo cielo.» Apud H. Corbin, La philosophie iranienne islamique aux XVII et XVIII siècles, París: Buchet/Chastel, 1981, p. 286.

64 «El Paraíso es una primavera eterna, un jardín siempre en flor, que refrescan aguas vivas; es también un estado definitivo e incorruptible como los minerales preciosos, el cristal y el oro. El arte persa y en especial la ornamentación de las mezquitas safávidas, consigue combinar ambas cualidades: la pureza de las líneas arquitectónicas, la perfecta geometría de las superficies abovedadas y la decoración con formas rectilíneas, expresan el estado cristalino; la primavera celestial brota en las flores estilizadas y en los colores frescos, ricos y suaves de los azulejos.» Burckhardt, El arte del Islam, o.c., p. 45. Véase a su vez S. H. Nasr, Islamic Art and Spirituality, Ipswich (Suffolk): Golgonooza Press, 1987.

65 Cf. Cor. 38:49: «Cierto, los piadosos tendrán un hermoso lugar (el Paraíso) de retorno (final)». Sobre la imagen espiritual del Paraíso, cf. Ardalan, «The Paradise Garden Paradigm», o.c., pp. 97-127. 
«Como conclusión, se puede afirmar que la mezquita persa, con su patio que simboliza el jardín cerrado del Paraíso, sus cuatro $\bar{\imath} w \bar{a} n$-es que son las grutas frescas donde el agua chorrea estalactitas como fuentes eternas de las que brotan los cuatro ríos del Edén, su bóveda celeste que, mirándose en las aguas inmemoriales del estanque purificador, forma una esfera cósmica que incluye el universo en su totalidad, y finalmente, su cúpula en forma de Árbol de la Vida, con ramajes densos que proyectan una sombra permanente y benéfica, sugiere las ciudades de la eternidad que describen las visiones místicas del Islam šịín.

Y esta sabia transfiguración del edificio de plegaria no ha sido posible sino gracias a la rica policromía de los azulejos. A ella y a su sinfonía de colores la mezquita persa debe el que se vista con la ropa de los símbolos inextinguibles que hacen de ella un análogo del Paraíso» ${ }^{66}$.

Ciertamente cuando se contempla la belleza de los azulejos del mausoleo del sultán Öljeitü en Sultāniyyeh (erigido en 1304), los refinados alicatados del período timúrida de la Mezquita Azul de Tabrīz (construida ca. 1460), así como la loza vidriada de las cúpulas safávidas de Isfahān, viene a la memoria una expresión que aparece con frecuencia en los versos de Ḥāfiz: per. gunbad-i minna o dā'irayi mīnā, «cúpula miniada», que significa la forma esférica del cielo y su color azul; minna lit. «piedra azul; color verde; piedra similar al lapislázuli; alquimia; esmalte; cielo, la bóveda azul celeste...».

«Ayer, le planteé mi problema al anciano mago (pīr-i mughān $)^{67}$ que, gracias a su facultad contemplativa, supo resolver el enigma.

Le encontré alegre y riendo, con el cubilete en la mano, y en este espejo (äyna) [que refleja la belleza divina, el rostro del Bienamado] él contemplaba cien colores.

Le dije: este cubilete que permite ver el mundo, - ¿cuándo te lo dio el sabio (Señor)? Él respondió: el día que él creó esta cúpula azur (gunbad-i miñ̄a ${ }^{68}$

66 Stierlin, Ispahan, Image du Paradis, o.c., p. 186.

67 El mago $(m u g h)$ es el sacerdote de la antigua religión mazdea dualista de Irán. Para Hāfiz es el iniciado, el gnóstico, y también el iniciador.

68 Ḥāfiż, ed. de Qazwīnī-Ghanī, 142, 3-5. La pareja de este cubilete mágico es el espejo fabuloso del Alejandro mítico y coránico, que también revela los secretos de la creación, ib., 5, 11. Véase J. Ch. Bürgel, «Le poète et la poésie dans l'œuvre de Hāfez», en Convegno internazionale sulla poesia di Hāfez (Roma, $30-31$ marzo 1976), Roma: Accademia Nazionale dei Lincei, 1978, pp. 90-1. 
Irán es la tierra en la que se produce el encuentro entre el Cielo y la Tierra: como en la topografía visionaria de la poesía de Hāfiz, en la que por medio de un espejo a dos niveles, lo sensible habla de lo suprasensible y lo suprasensible habla de lo sensible ${ }^{69}$. Tanto el ojo del poeta como su corazón y su poesía se comparan con un espejo; la función de la poesía es pues vista en un contexto neoplatónico donde todo el universo está dividido en esferas ontológicas según un orden jerárquico, en el que cada una recibe la luz de las otras y ora la envuelve, ora la devela o la refleja como un espejo ${ }^{70}$. La visión imaginal de la cúpula azur (gunbad-i minnā) de Ḥāfiz tiene su expresión sensible en la cúpula de loza esmaltada que corona el bello mausoleo del gran maestro sufi Ni‘matullāh Walī Kirmānī, santuario situado en Māhān (al sur de Kirmān) ${ }^{71}$, oasis rodeado por la inmensidad del desierto; cúpula de color azul turquesa que se mezcla con el azul intenso del cielo. Si los mosaicos de ladrillo vidriado de este santuario safávida de Ni‘matullāh Walī (que data de 1436-1601 d.C.) representan el azul turquesa del cielo espiritual, la bella Mezquita Azul (masğid-i kabūd) de Tabrīz (construida en 1465 d.C.), al noroeste de Irán, simboliza el azul lapislázuli del universo insondable.

69 Véase D. Shayegan, «La Topographie visionnaire de Hāfez de Shīrāz», Cahiers de l’Université Saint-fean de férusalem, 7, París: Berg International, 1981.

70 Véase la descripción detallada y brillante de esta estructura universal de luz en Hikmat al-išrāq, de Šihāb alDīn Yahyà Suhrawardī.

71 Cf. M. A. Amir-Moezzi, «Jamkarān et Māhān: deux pèlerinages insolites en Iran», en M. A. Amir-Moezzi (dir.), Lieux d'Islam. Cultes et cultures de l'Afrique à Java, París: Autrement, 1996, pp. 164-6. 